\title{
Independent iron and light limitation in a low-light-adapted Prochlorococcus from the deep chlorophyll maximum
}

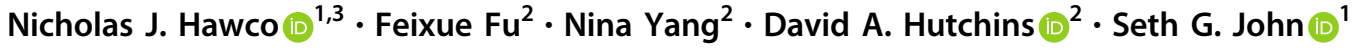

Received: 10 April 2020 / Revised: 25 August 2020 / Accepted: 10 September 2020 / Published online: 23 September 2020

(c) The Author(s) 2020. This article is published with open access

\begin{abstract}
Throughout the open ocean, a minimum in dissolved iron concentration $(\mathrm{dFe})$ overlaps with the deep chlorophyll maximum (DCM), which marks the lower limit of the euphotic zone. Maximizing light capture in these dim waters is expected to require upregulation of Fe-bearing photosystems, further depleting $\mathrm{dFe}$ and possibly leading to co-limitation by both iron and light. However, this effect has not been quantified for important phytoplankton groups like Prochlorococcus, which contributes most of the productivity in the oligotrophic DCM. Here, we present culture experiments with Prochlorococcus strain MIT1214, a member of the Low Light 1 ecotype isolated from the DCM in the North Pacific subtropical gyre. Under a matrix of iron and irradiance matching those found at the DCM, the ratio of Fe to carbon in Prochlorococcus MIT1214 cells ranged from $10-40 \times 10^{-6} \mathrm{~mol} \mathrm{Fe}: \mathrm{mol} \mathrm{C}$ and increased with light intensity and growth rate. These results challenge theoretical models predicting highest $\mathrm{Fe}: \mathrm{C}$ at lowest light intensity, and are best explained by a large photosynthetic $\mathrm{Fe}$ demand that is not downregulated at higher light. To sustain primary production in the DCM with the rigid Fe requirements of low-light-adapted Prochlorococcus, dFe must be recycled rapidly and at high efficiency.
\end{abstract}

Since its emergence several hundred million years ago, the Prochlorococcus genus has diversified into dozens of distinct subpopulations, but the main branches of this radiation (ecotypes) are structured primarily by their growth at different irradiance [1]. Upregulation of the photosynthetic apparatus in low-light-adapted ecotypes compensates for dwindling light flux, contributing to the formation of a DCM layer at the base of the euphotic zone [2]. As photosynthetic proteins represent a large pool of $\mathrm{Fe}$ in these cells, growth at low light is expected to increase

Supplementary information The online version of this article (https:// doi.org/10.1038/s41396-020-00776-y) contains supplementary material, which is available to authorized users.

$\triangle$ Nicholas J. Hawco

hawco@hawaii.edu

1 Department of Earth Sciences, University of Southern California, Los Angeles, CA, USA

2 Marine and Environmental Biology, University of Southern California, Los Angeles, CA, USA

3 Present address: Department of Oceanography, School of Ocean and Earth Sciences and Technology, University of Hawai' $i$ at Mānoa, Honolulu, HI, USA photosynthetic Fe requirements [3], an effect that has been documented in temperate diatoms and other model phytoplankton $[4,5]$. The stratification of Prochlorococcus ecotypes therefore implies a stratification of Fe requirements, such that low light at depth would be coupled to very high Fe demand.

Large Fe requirements may lead to Fe stress in the DCM, where $\mathrm{dFe}$ can fall below $10^{-10} \mathrm{~mol} \mathrm{~L}^{-1}(100 \mathrm{pM}$ [6]). Incubations in the California Current have shown that diatoms and other eukaryotic phytoplankton at the DCM respond to increases in both $\mathrm{Fe}$ and light [7], but these taxa are less abundant in offshore waters. At Station ALOHA-a site that is broadly representative of the North Pacific Subtropical Gyre-most primary production in the DCM (100-125 m depth) is accomplished by low-light-adapted Prochlorococcus ecotypes [8,9] whose Fe requirements have not been characterized.

We quantified the Fe requirements of Prochlorococcus MIT1214, a member of the LL1 ecotype isolated from Station ALOHA, under a matrix of $\mathrm{Fe}$ and irradiance typical of the DCM (see Supplementary Materials and Methods), which follows the $0.5 \mathrm{~mol}$ photon $\mathrm{m}^{-2} \mathrm{day}^{-1}$ isolume [10] and overlaps with peak abundance of LL1 Prochlorococcus (0.1-1 mol photon $\mathrm{m}^{-2}$ day $^{-1}$ [9]). Under Fe-replete conditions $\left(>150 \mathrm{pM} \mathrm{Fe}^{\prime}\right)$, specific growth rates $(\mu)$ of 
Fig. 1 Growth of

Prochlorococcus MIT1214 under low iron and low light. Specific growth rates as a function of a irradiance under Fe-replete conditions and b bioavailable $\mathrm{Fe}$ concentrations $\left(\mathrm{Fe}^{\prime}\right)$. c The $\mathrm{Fe}: \mathrm{C}$ ratio and d chlorophyll $a$ :C ratio in harvested cells as a function of $\mathrm{Fe}^{\prime}$. Error bars reflect the range of triplicate measurements. Shading highlights typical irradiance [10] and $\mathrm{dFe}[6]$ at the DCM of Station ALOHA in the North Pacific Subtropical Gyre, where Prochlorococcus MIT1214 was originally isolated.
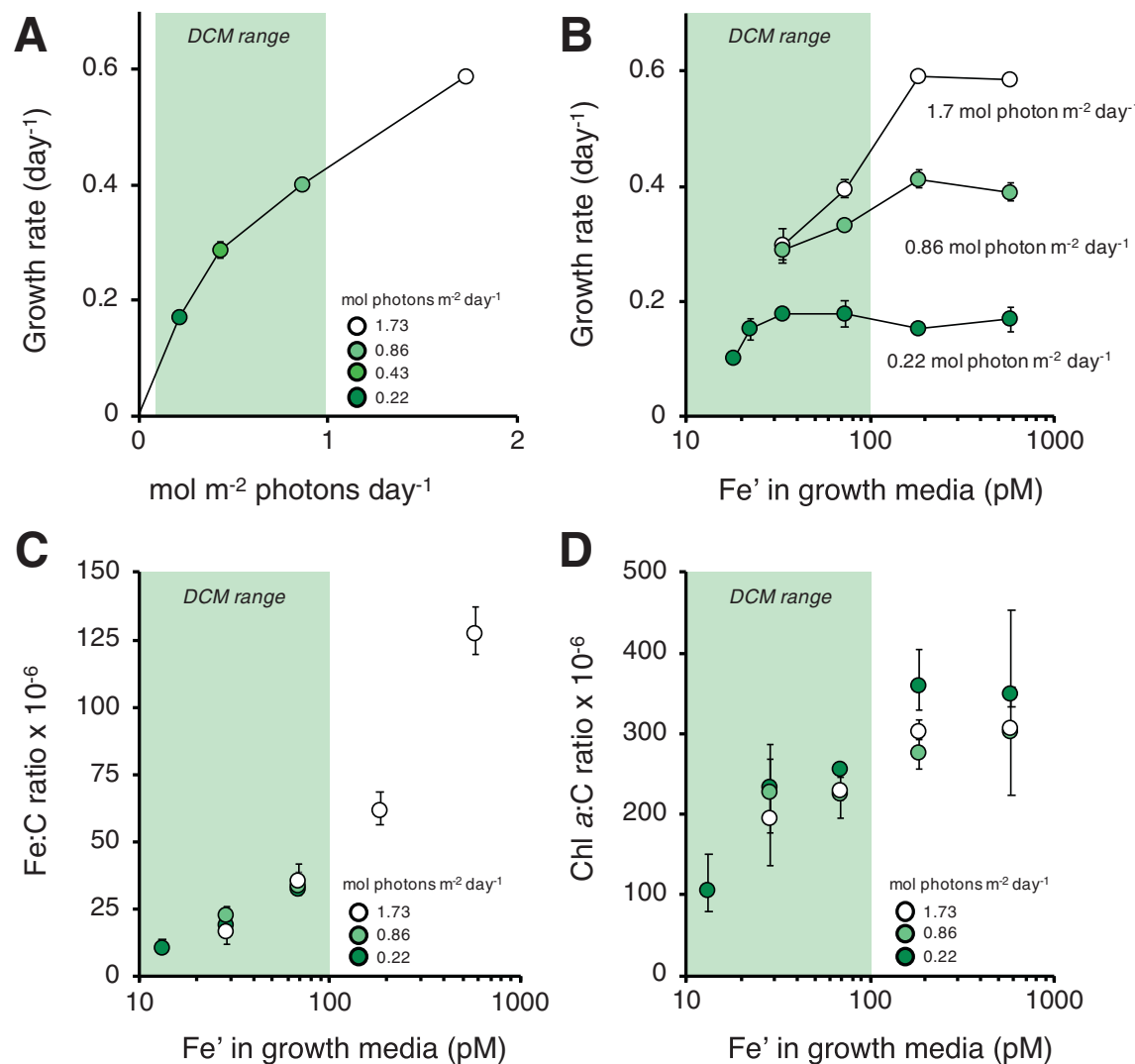

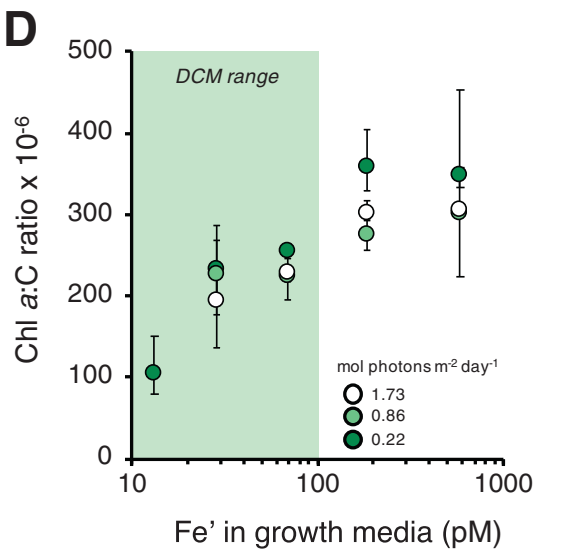

A
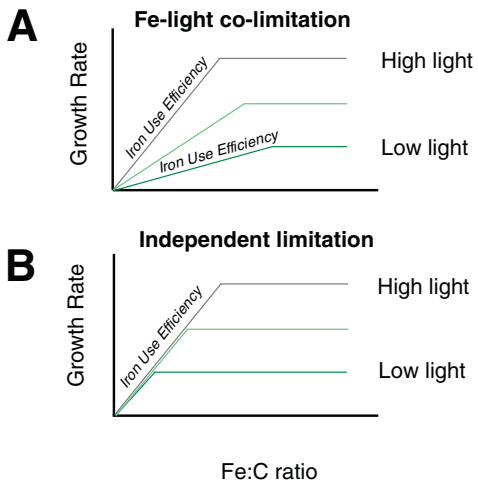

Fig. 2 An empirical test of Fe-light co-limitation. Predicted relationships between $\mathrm{Fe}: \mathrm{C}$ and growth rate under a a state of Fe-light colimitation, or $\mathbf{b}$ independent states of light limitation and Fe limitation. The slope between growth rate and $\mathrm{Fe}: \mathrm{C}$ corresponds to the iron use efficiency (IUE). c Observed relationships between growth rate and

Prochlorococcus MIT1214 were dependent on irradiance (Fig. 1a), indicating that LL1 Prochlorococcus at the DCM are in a light-limited regime. At $1.7 \mathrm{~mol}$ photon $\mathrm{m}^{-2}$ day $^{-1}$, growth became $\mathrm{Fe}$-limited at a bioavailable iron concentration $\left(\mathrm{Fe}^{\prime}\right)$ of $73 \mathrm{pM}$, which intensified at $33 \mathrm{pM} \mathrm{Fe}^{\prime}$ (Fig. 1b). These concentrations also limited growth at $0.86 \mathrm{~mol}$ photon $\mathrm{m}^{-2}$ day $^{-1}$ but not at 0.22 mol photon $\mathrm{m}^{-2}$ day $^{-1}$. Fe limitation at 0.22 mol photon $\mathrm{m}^{-2}$ day $^{-1}$ was only observed below $20 \mathrm{pM} \mathrm{Fe}^{\prime}$. In all treatments, the $\mathrm{Fe}: \mathrm{C}$

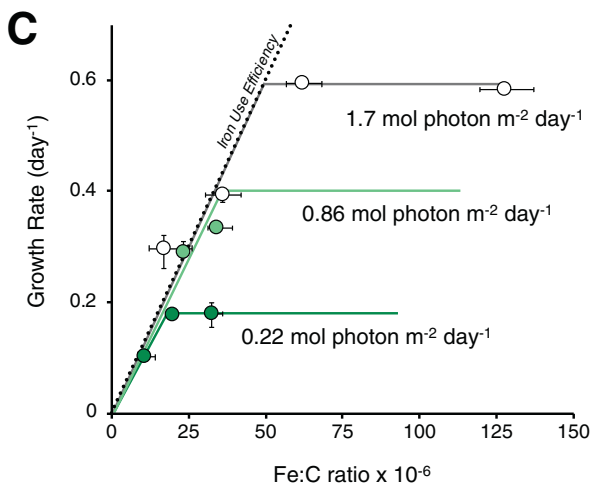

cellular Fe:C ratios for Prochlorococcus MIT1214 at 0.22 (dark green circles), 0.86 (light green), and $1.7 \mathrm{~mol}$ photon $\mathrm{m}^{-2} \mathrm{day}^{-1}$ (white). Experimental data are consistent with predictions for independent states of Fe and light limitation, following an IUE of $1.2 \times 10^{4} \mathrm{~mol} \mathrm{C}$ mol Fe ${ }^{-1}$ day $^{-1}$ (dotted black line).

composition of harvested cells primarily reflected $\mathrm{Fe}^{\prime}$ (Fig. 1c), but greater Fe:C was needed for faster growth rates at greater irradiance. At saturating light $\left(1.7 \mathrm{~mol}\right.$ photon $\mathrm{m}^{-2}$ day $\left.^{-1}\right)$, cells bearing an $\mathrm{Fe}: \mathrm{C}$ ratio of $36 \pm 6 \times 10^{-6}$ were still Fe-limited while cells growing at low light $(0.22 \mathrm{~mol}$ photon $\mathrm{m}^{-2}$ day $^{-1}$ ) reached peak growth rate with an $\mathrm{Fe}: \mathrm{C}$ ratio of $20 \pm 2 \times 10^{-6}$ (Table S1).

Smaller Fe requirements at lower irradiance is counter to models of Fe-light co-limitation, which is predicted from 
theory [3] and has been observed in model diatoms [4] and cyanobacteria [5]. In this state, either increased light or increased $\mathrm{Fe}$ can lead to higher growth rate: greater $\mathrm{Fe}$ supply will enable the construction of more photosynthetic units (PSU), allowing more light to be absorbed, increasing growth. Alternatively, an increase in irradiance will increase photon absorption with a fixed number of PSU. Fe-light colimitation should manifest in the iron use efficiency (IUE) of growth, which describes the rate that cells accumulate biomass $\mathrm{C}$ per catalytic $\mathrm{Fe}$ atom. The IUE can be identified empirically as the slope between cellular Fe:C and $\mu$ under Fe-limiting conditions (Fig. 2). Fe-light co-limitation will cause the IUE to vary under different light regimes (Fig. 2a), with values proportional to the difference in photon flux [3]. In contrast, if Fe limitation and light limitation are independent physiological states (i.e. if low light does not increase Fe requirements), then a single IUE would apply for multiple light levels (Fig. 2b). Our observations of Prochlorococcus MIT1214 most closely reflect the latter scenario (Fig. 2c), which follow an IUE of $1.2 \times 10^{4} \mathrm{~mol} \mathrm{C}$ mol Fe ${ }^{-1}$ day $^{-1}$. Thus, Prochlorococcus MIT1214 does not appear to be subject to Fe-light co-limitation under conditions relevant to the DCM.

The magnitude of IUE in Prochlorococcus MIT1214 is similar to both the theoretical IUE of a generic photoautotrophic cell $\left(1.15 \times 10^{4} \mathrm{~mol} \mathrm{C} \mathrm{mol} \mathrm{Fe}^{-1}\right.$ day $^{-1}$ at $0.5 \mathrm{~mol}$ photon $\mathrm{m}^{-2} \mathrm{day}^{-1}$ [3]) and the empirical IUE of temperate eukaryotic phytoplankton under light limitation $\left(0.97 \times 10^{4} \mathrm{~mol} \mathrm{C} \mathrm{mol} \mathrm{Fe}{ }^{-1} \mathrm{day}^{-1}\right.$ [4]). Convergence between these estimates suggests that theoretical IUE calculations apply to Prochlorococcus MIT1214 but, unlike classical descriptions of Fe-light co-limitation, the number of PSUs (and therefore the Fe requirement) is not downregulated in response to increases in light. This interpretation is supported by the $<15 \%$ difference in chlorophyll $a$ :C ratios of Fe-replete Prochlorococcus MIT1214 grown at 0.22 and 1.7 mol photon $\mathrm{m}^{-2}$ day $^{-1}$ (Fig. 1d; $\mathrm{Fe}^{\prime}>150 \mathrm{pM}$; ANOVA with post-hoc Tukey test, $p>0.05$ ), and by the much higher IUE achieved by the high-light adapted strain Prochlorococcus MIT9215 $\left(1.5 \times 10^{5} \mathrm{~mol} \mathrm{C} \mathrm{mol} \mathrm{Fe}{ }^{-1}\right.$ day $\left.^{-1}\right)$ when grown at greater irradiance [11].

The absence of Fe-light co-limitation has also been observed in Southern Ocean phytoplankton capable of producing large photosynthetic antennae ( 2000 chlorophyll molecules per PSU) that enable very high IUE and Fe:C ratios below $3 \times 10^{-6}$ [12]. Low-light-adapted Prochlorococcus construct considerably smaller antennae (272 chlorophyll per PSU; Table S2), perhaps due to photochemical inefficiencies at the very low irradiance and warmer temperatures found in the DCM of subtropical gyres [12]. Based on the size of these antennae (300 and $360 \mathrm{~nm}^{2}$ for PSII and PSI, respectively [13]), an estimated $4.5 \mu \mathrm{m}^{2}$ of photosynthetic membrane in a low-light-adapted
Prochlorococcus cell can be populated with a maximum of $6700 \mathrm{PSU}$ containing 134,000 Fe atoms (assuming a 1:1 ratio of PSI:PSII and $20 \mathrm{Fe}$ atoms per PSU, see Supplementary Information for full calculation). Thus, a cell with $4 \mathrm{fmol} \mathrm{C}\left(2.41 \times 10^{9}\right.$ atoms $)$ and maximally upregulated PSU would be expected to have an $\mathrm{Fe}: \mathrm{C}$ ratio of $56 \times 10^{-6}$, which is similar to our measurements (although the latter also includes a small $\mathrm{Fe}$ requirement associated with respiration [3]). Under DCM conditions, it may not be possible for other ecotypes to achieve substantially lower Fe:C without first developing larger antennae, which has not been demonstrated. The genomes of Prochlorococcus MIT1214 and other LL1 isolates already contain seven copies of the $p c b$ gene, encoding the chlorophyll binding proteins that compose the antennae to PSI and PSII, which is comparable to the eight copies in extremely low-lightadapted SS120 strain [13, 14]. Furthermore, the absence of two putative ferredoxins in LL1 genomes (Table S3), a feature shared by the 'HNLC' ecotypes [15], suggests that LL1 Prochlorococcus have undergone some level of adaptation to low Fe in the lower euphotic zone.

In the North Pacific subtropical gyre, the abundance of LL1 Prochlorococcus peaks at $105 \pm 18 \mathrm{~m}$ depth [9], where primary production is $0.17 \pm 0.09 \mu \mathrm{M} \mathrm{C}$ day $^{-1}$ (mean at $100 \mathrm{~m}$ at Station ALOHA). To avoid Fe limitation, our results indicate Prochlorococcus must maintain an $\mathrm{Fe}: \mathrm{C}$ ratio above $30 \times 10^{-6}$, requiring uptake of at least $5.1 \pm 2.7 \mathrm{pM} \mathrm{Fe} \mathrm{day}^{-1}$ from a small $\mathrm{dFe}$ inventory $(64 \pm 20 \mathrm{pM}$ for $90-120 \mathrm{~m} \mathrm{[6])}$. Although this estimate can be further refined by characterizing co-occurring Prochlorococcus ecotypes and other phytoplankton found in the DCM, it implies that Fe in the lower euphotic zone turns over on the order of $13 \pm 8$ days (or less), substantially shorter than the 6-12 month residence time of $\mathrm{dFe}$ inferred at Station ALOHA [16]. Therefore, severe iron limitation could develop at the DCM if $\mathrm{dFe}$ is not recycled over a dozen of times before being scavenged or exported to depth. The need for high-efficiency Fe recycling likens the DCM to the Equatorial Pacific and other Fe-limited regions $[17,18]$, and may motivate the synthesis of siderophores in the lower euphotic zone [19].

Acknowledgements We thank Alison Coe and the Chisholm Lab at MIT for providing cultures of Prochlorococcus MIT1214ax. This work was supported by Simons Foundation Awards 329108 to SGJ and 602538 to NJH, and National Science Foundation awards OCE 1657757 and OCE 1851222 to DAH and FFU. We also thank Shane Hogle and two anonymous reviewers for constructive comments that substantially improved this work.

\section{Compliance with ethical standards}

Conflict of interest The authors have no conflicts of interest to declare.

Publisher's note Springer Nature remains neutral with regard to jurisdictional claims in published maps and institutional affiliations. 
Open Access This article is licensed under a Creative Commons Attribution 4.0 International License, which permits use, sharing, adaptation, distribution and reproduction in any medium or format, as long as you give appropriate credit to the original author(s) and the source, provide a link to the Creative Commons license, and indicate if changes were made. The images or other third party material in this article are included in the article's Creative Commons license, unless indicated otherwise in a credit line to the material. If material is not included in the article's Creative Commons license and your intended use is not permitted by statutory regulation or exceeds the permitted use, you will need to obtain permission directly from the copyright holder. To view a copy of this license, visit http://creativecommons. org/licenses/by/4.0/.

\section{References}

1. Biller SJ, Berube PM, Lindell D, Chisholm SW. Prochlorococcus: the structure and function of collective diversity. Nat Rev Micro. 2015;13:13-27.

2. Moore LR, Rocap G, Chisholm SW. Physiology and molecular phylogeny of coexisting Prochlorococcus ecotypes. Nature. 1998; 393:464-7.

3. Raven JA. Predictions of $\mathrm{Mn}$ and Fe use efficiencies of phototrophic growth as a function of light availability for growth and of $\mathrm{C}$ assimilation pathway. N Phytol. 1990;116:1-18.

4. Sunda WG, Huntsman SA. Interrelated influence of iron, light and cell size on marine phytoplankton growth. Nature. 1997; 390:389-92.

5. Sunda WG, Huntsman SA. High iron requirement for growth, photosynthesis, and low-light acclimation in the coastal cyanobacterium Synechococcus bacillaris. Front Microbiol. 2015;6:561.

6. Fitzsimmons JN, Hayes CT, Al-Subiai SN, Zhang R, Morton PL, Weisend RE, et al. Daily to decadal variability of size-fractionated iron and iron-binding ligands at the Hawaii Ocean Time-series Station ALOHA. Geochim Cosmochim Acta. 2015;171:303-24.

7. Hogle SL, Dupont CL, Hopkinson BM, King AL, Buck KN, Roe KL, et al. Pervasive iron limitation at subsurface chlorophyll maxima of the California Current. Proc Natl Acad Sci. 2018; $115: 13300-5$
8. Rii YM, Karl DM, Church MJ. Temporal and vertical variability in picophytoplankton primary productivity in the North Pacific Subtropical Gyre. Mar Ecol Prog Ser. 2016;562:1-18.

9. Malmstrom RR, Coe A, Kettler GC, Martiny AC, Frias-Lopez J, Zinser ER, et al. Temporal dynamics of Prochlorococcus ecotypes in the Atlantic and Pacific oceans. ISME J. 2010;4:1252.

10. Letelier RM, Karl DM, Abbott MR, Bidigare RR. Light driven seasonal patterns of chlorophyll and nitrate in the lower euphotic zone of the North Pacific Subtropical Gyre. Limnol Oceanogr. 2004;49:508-19.

11. Hawco NJ, Mcilvin MR, Bundy RM, Tagliabue A, Moran DM, Valentin-Alvarado L, et al. Minimal cobalt metabolism in the marine cyanobacterium Prochlorococcus. Proc Natl Acad Sci. 2020;117:15740-7.

12. Strzepek RF, Boyd PW, Sunda WG. Photosynthetic adaptation to low iron, light, and temperature in Southern Ocean phytoplankton. Proc Natl Acad Sci. 2019;116:4388-93.

13. Bibby TS, Mary I, Nield J, Partensky F, Barber J. Low-lightadapted Prochlorococcus species possess specific antennae for each photosystem. Nature. 2003;424:1051-4.

14. Berube PM, Rasmussen A, Braakman R, Stepanauskas R, Chisholm SW. Emergence of trait variability through the lens of nitrogen assimilation in Prochlorococcus. Elife. 2019;8:e41043.

15. Rusch DB, Martiny AC, Dupont CL, Halpern AL, Venter JC. Characterization of Prochlorococcus clades from iron-depleted oceanic regions. Proc Natl Acad Sci. 2010;107:16184-9.

16. Hayes CT, Fitzsimmons JN, Boyle EA, McGee D, Anderson RF, Weisend $\mathrm{R}$, et al. Thorium isotopes tracing the iron cycle at the Hawaii Ocean Time-series Station ALOHA. Geochim Cosmochim Acta. 2015;169:1-16.

17. Rafter PA, Sigman DM, Mackey KRM. Recycled iron fuels new production in the eastern equatorial Pacific Ocean. Nat Commun. 2017;8:1-10.

18. Boyd PW, Law CS, Hutchins DA, Abraham ER, Croot PL, Ellwood M, et al. FeCycle: attempting an iron biogeochemical budget from a mesoscale $\mathrm{SF}_{6}$ tracer experiment in unperturbed low iron waters. Global Biogeochem Cycles. 2005;19:GB4S20. https://doi.org/10.1029/2005GB002494.

19. Bundy RM, Boiteau RM, McLean C, Turk-Kubo KA, McIlvin MR, Saito MA, et al. Distinct siderophores contribute to iron cycling in the mesopelagic at station ALOHA. Front Mar Sci. 2018;5:61. 